\title{
EVALUATION OF INHIBITORY AND ANTIOXIDANT ACTIVITIES OF FREE ESSENTIAL OILS AND NANOEMULSIONS ON TRICHOMONAS VAGINALIS ${ }^{1}$
}

\author{
AVALIAÇÃO DA ATIVIDADE INIBITÓRIA E ANTIOXIDANTE DE \\ ÓLEOS ESSENCIAIS LIVRES E NANOEMULSÕES \\ SOBRE TRICHOMONAS VAGINALIS ${ }^{1}$
}

\author{
Juliana Montelli Fenalti², Bruna Baccega'2, Mirian Bruni², Paloma Birmann², \\ Raquel Neves ${ }^{3}$, Alexia Mello ${ }^{4}$, Yan Islabão ${ }^{4}$, Samanta Gündel ${ }^{5}$, Maiara Callegaro Velho ${ }^{5}$, \\ Samantha Nunes de Godoi ${ }^{5}$, Aline Ferreira Ourique ${ }^{5}$, Daiane Acosta ${ }^{6}$, Lucielli Savegnago ${ }^{6}$, \\ Dulce Stauffert ${ }^{6}$, Nara Amélia Da Rosa Farias ${ }^{7}$ e Camila Belmonte Oliveira ${ }^{7}$
}

\begin{abstract}
Trichomoniasis, an infection caused by Trichomonas vaginalis, is the most commom non-viral sexually transmitted infection worldwide. Due to Metronidazole's (MTZ) resistance to standard drugs, this study aimed to evaluate the efficacy of free and nanostructured essential oils (EO) as Cymbopogon flexuosus (lemongrass), Eucalyptus globulus (eucalyptus) and Ocimum basilicum (basil), besides antioxidant activities against $T$. vaginalis. The free and nanostructured EOs were tested for in vitro activity against Trichomonas vaginalis; trophozoites were treated with different concentrations (ranging from $0.25 \%$ to $1.5 \%$ ) in order to establish the MIC and IC50 values. Oxidative stress was also evaluated by measuring lipid peroxidation by the detection of thiobarbituric acid reactive substances (TBARS). The MIC observed for lemongrass was $1.5 \%$ with free oil and $1.0 \%$ with nanoemulsion, while for basil it was $1.5 \%$ with free and nanostructured oils. Significant antiparasitic activities were observed in 12 and 24 hours exposure, respectively, inhibiting 100\% of trophozoites. Antioxidant activity was also observed in these oils, which, either in free or nanostructured form, were able to reduce lipid peroxidation.
\end{abstract}

Keywords: Cymbopogon flexuosus, Eucalyptus globulus, Nanotechnology, Ocimum basilicum, Trichomoniasis.

\section{RESUMO}

Tricomoníase, infecção causada pelo Trichomonas vaginalis é a infecçãoo sexualmente transmissível não viral mais comum do mundo. Devido a resistência do Metronidazol (MTZ), droga padrão, este estudo teve como objetivo avaliar a eficácia dos óleos essenciais (OEs) livres e nanoestruturados de Cymbopogon flexuosus (capim-limão), Eucalyptus globulus (eucalipto) e Ocimum basilicum (manjericão) além de atividade antioxidante contra T. vaginalis. OEs livres e nanoestruturados tiveram a sua atividade in vitro

\footnotetext{
${ }^{1}$ Artigo oriundo de Tese.

${ }^{2}$ Alunas de Doutorado - Universidade Federal de Pelotas (UFPel). E-mails: jufenalti@hotmail.com; brubaccega@ hotmail.com; mirianbruni@gmail.com; paloma_birmann@hotmail.com

${ }^{3}$ Colaboradora - Universidade Federal de Santa Catarina (UFSC). E-mail:raquelneeves@hotmail.com

${ }^{4}$ Alunos de graduação - Universidade Federal de Pelotas (UFPel). E-mail: alexiabraunermello@gmail.com; yanwahast06@, gmail.com

${ }^{5}$ Colaboradoras - Universidade Franciscana (UFN). E-mails: samantagundel@hotmail.com; maiaracvelho@hotmail.com; sam.nunes.godoi@gmail.com; alineourique@hotmail.com

${ }^{6}$ Colaboradores - Universidade Federal de Pelotas (UFPel).E-mail: day-acosta@hotmail.com; luciellisavegnago@yahoo.com.br ${ }^{7}$ Orientadoras - Universidade Federal de Pelotas (UFPel). E-mail: naraameliafarias@gmail.com; camilabelmontevet@ yahoo.com.br
} 
testada contra T. vaginalis; trofozoitos foram tratados com concentrações diferentes (variando de $0.25 \%$ a 1.5\%) a fim de estabelecer o valor de MIC e $I C_{50}$. O estresse oxidativo também foi avaliado medindo a peroxidação lipídica através da detecção de Substâncias Reativas ao Ácido Tiobarbitúrico (TBARS). O MIC observado para o capim-limão foi de $1.5 \%$ para o óleo livre e de $1.0 \%$ para nanoemulsão, enquanto o manjericão foi de $1.5 \%$ para o óleo nanoestrututrado e livre. Foi observado significante atividade antiparasitária em 12 e 24 horas de exposição, respectivamente, inibindo 100\% dos trofozoitos. Atividade antioxidante também foi observado nestes óleos, tanto na forma livre ou nanoestruturado foi capaz de reduzir a peroxidação lipídica.

Palavras-chave: Cymbopogon flexuosus, Eucalyptus globulus, Nanotecnologia, Ocimum basilicum, Tricomoníase.

\section{INTRODUCTION}

Trichomoniasis is the most commom non-viral sexually transmited infeccion in the world. This infection is caused by the flagellated protozoan Trichomonas vaginalis (MUZNY, 2018). This parasite is considered the main agent responsible for the occurrence of vaginitis in women, and has alsobeen associated to infertility, cervical cancer, pelvic inflammatory disease, preterm birth, and low birth weight. Besides, it has been indicated that it is a risk factor for human immunodeficiency virus acquisition and transmission (KISSINGER, 2015).

Since 1959, metronidazole (MTZ) has been the drug of choice for the treatment of trichomoniasis. A $2 \mathrm{~g}$ single oral dose or $500 \mathrm{mg}$ twice daily for 7 days is the recommended treatment. The latter regimen is suggested for $\mathrm{HIV}$-infected or recidives patients. Side effects such as nausea vomiting and epigastric pain represent a barrier for patients finishing the protocol of treatment, which cause the emergence of resistant strains (DUNNE et al., 2003; CUDMORE et al., 2004).

Despite the known efficacy of MTZ, drug resistance has increased since 1962. Faced with several reports os resistance, natural products have been important sources of novel therapeutic options. The literature demonstrates the remarkable performance of essential oils (EOs), derived from the secondary metabolism of plants, showing the many biological activities of this compounds (BILIA et al., 2014). Due to their lipophilic and chemical characteristics, EOs can be incorporated into nanostructures. Nanotecnology is an alternative to facilitate and improve their absorption and distribution to target cells, besides reducing volatility and instability through their incorporation into nanocapsules (COUVREUR;VAUTHIER, 2006; DANIELLI et al., 2013; SALVIA-TRUJILLO et al., 2015; CHANG et al., 2015). Thus, the aim of this study was to evaluate the efficacy of essential oils of Cymbopogon flexuosus (lemongrass), Eucalyptus globulus (eucalyptus) and Ocimum basilicum (basil) against T. vaginalis, both free and nanostructured forms. 


\section{MATERIAL AND METHODS}

\section{Trichomonas vaginalis recovered and Method of culture}

Samples were collected at the Clinic of Gynecology and Obstetrics in the Infant and Maternal Department of the School of Medicine (FAMED) of the Universidade Federal de Pelotas (UFPel), during routine medical appointments. Swab was to isolate and keep the axenic culture, trophozoites were inoculated in TYM (trypticase-yeast-extract-maltose) medium, $\mathrm{pH}$ 6.0, supplemented with 10\% inactivated bovine serum at $37^{\circ} \mathrm{C}$ (DIAMOND, 1957). Isolates were sub-cultured every 24 hours in new culture tube containing complete TYM medium and maintained at laboratory.

\section{Ethics}

All procedures performed in this study involving human participants were in accordance with the ethical standards of the Ethics Committee of the School of Medicine, Federal University of Pelotas (Committee Approval number 873.180) and National Commission on Ethics in Research (amendment 1.838.829).

\section{In vitro assay}

The culture samples were collected and viable trophozoites were counted in a Neubauer cellcounter chamber, in triplicate, to adjusted the final density to $2.6 \times 10^{5}$ trophozoites $/ \mathrm{ml}$ culture. The tests were performed at $37{ }^{\circ} \mathrm{C}$ at atmosphere of $5 \% \mathrm{CO}_{2}$, in nonoplicate, in 96 wells microtiter plates following SENA-LOPES et al., (2018), adapted. From the stock solution with free and nanoemulsion oils $(100 \%)$, dilutions in TYM medium were prepared at double the concentration desired for testing. Free and nanostructured oils were added to each well containing $100 \mu \mathrm{L}$ of medium with T. vaginalis trophozoites to reach a final concentration of $0.25 \%, 0.5 \%, 1.0 \%$, and $1.5 \%$. The viability of the trophozoites in the culture plate was evaluated by $0.4 \%$ trypan blue dye exclusion and quantified in a cell-counter chamber using a hemocytometer. Also, theanalysis determined the IC50 (half the maximum inhibitory concentration) and evaluated the minimal inhibitory concentration (MIC) of the free oils or nanoemulsions that were able to inativate $100 \%$ of viable trophozoites at the screening. To determine the MIC, the kinetic growth of cells was checked after 1, 6, 12, 24, 48, 72, and $96 \mathrm{~h}$. MIC was confirmed by the failure of non-motile parasites to grow. Additionaly, there was also the evaluation of four controls containing trophozoites with: TYM medium (negative control-NC), $25 \mu \mathrm{g} / \mathrm{mL}$ metronidazole Sigma-Aldrich ${ }^{\circledR}$ (positive control), control of Tween (TW) 80 0.01\% (solubilizer) and blank nanoemulsions $(\mathrm{BN})$. The same screening procedure was applied for all tests. 


\section{Essential oil}

The essential oils of lemongrass (C. flexuosus) and eucalyptus (Eucalyptus globulus) were commercially obtained respectively from FERQUIMA Indústria e Comércio de Oliveira, and basil (O. basilicum) from Sigma Aldrich (São Paulo, Brazil) Trade Ltda.

\section{Characterization of the essential oils}

The characterization of free essential oils of lemongrass, eucalyptus and basil were performed at the Nanotechnology Laboratory of the Fransciscana University of Santa Maria-RS (UFN), following the method by Hussain et al. (2008), adapted (GODOI et al., 2017; DA SILVA GÜNDEL et al., 2018a, 2018b).

\section{Development of nanoemulsions}

Nanoemulsions were developed by the Nanotechnology Laboratory (UFN) under high agitation method with homogenizator to incorporate the lemongrass, eucalyptus or basil EOs. The blank nanoemulsion was developed using a medium chain triglyceride, derived from caprylic and capric acids (GODOI et al., 2017; DA SILVA GÜNDEL et al., 2018a, 2018b).

\section{Characterization of nanoemulsions}

The physicochemical characterization of the formulations was evaluated at the same laboratory by determining the mean droplet size, polydispersity index, zeta potential and $\mathrm{pH}$ at the same day of production (DA SILVA GÜNDEL et al., 2018a).

\section{Thiobarbituric acid reactive species (TBARS) assay}

This assay evaluates the levels of lipid peroxidation. It was performed as described by Ohkawa et al. (1979), modified. An aliquot of the sample $(200 \mu \mathrm{l})$ was incubated with $8.1 \%$ sodium dodecyl sulfate (SDS) $(200 \mu \mathrm{l}), 0.8 \%$ thiobarbituric acid (TBA) $(500 \mu \mathrm{l})$ and acetic acid/ $\mathrm{HCl}(\mathrm{pH} 3.4)(500 \mu \mathrm{l})$ at $95^{\circ} \mathrm{C}$ during $60 \mathrm{~min}$. The levels of TBARS were measured spectrophotometrically at $532 \mathrm{~nm}$. The results were expressed as nmol TBARS/g tissue. 


\section{Statistical analysis}

The results of the in vitro tests are presented as percentages and were analyzed by an analysis of variance (ANOVA) followed by comparison with the Tukey test using the Graph Pad Prism 7.04 software. The significance level was $\mathrm{p}<0.05$.

\section{RESULTS}

The nanoemulsion formulation used in this study has nanometric size, with the average size of all nanoemulsions ranging from 66 to $127 \mathrm{~nm}$, a homogeneous size distribution as can be observed on the polydispersity index. The zeta potencial was also measured like $\mathrm{pH}$. The nanoemulsions containing C. flexuosus, O. basilicum and E. globulus had, respectively, average particle size of approximately $98 \pm 0.82,113 \pm 0.78,66 \pm 0.81$; polydispersion index of $0.20 \pm 0.007,0.19 \pm 0.007$, $0.23 \pm 0.004$; zeta potential of $-7.48 \pm 1.02,-8.47 \pm 0.98,-7.53 \pm 0.72$ and acidic $\mathrm{pH} 4.00 \pm 0.07$, $5.37 \pm 0.04,5.90 \pm 0.04$. The blank nanoemulsion maintained average particle size of approximately $127 \pm 1.02$, polydispersion index of $0.25 \pm 0.005$, zeta potential of $-6.37 \pm 0.58$, and $\mathrm{pH}$ of $5.15 \pm$ 0.03. The nanoemulsions possess adequade properties and morphology and preserved within 90 days the same quantity of major compounds when stored under refrigeration.

The major compounds were determined by gas chromatography. The major constituents identified in the C.flexuosus essential oil composition used in our study were $\beta$-geranial (45.74\%), Z-citral (34.42\%) and geraniol (6.01\%). The components of $O$. basilicum oil also were determined by gas chromatography. The major constituents of this oil were estragole (87\%), 1,8-cineole (3\%) and transalpha-bergamotene (2\%). The main components identified in the E. globulus oil were 1,8-cineole (75.7\%); p-cymene (7.5\%); alpha-pinene (7.3\%); and limonene (6.4\%).

The efficacy obtained with the free and nanostructured oils, MTZ and controls used for the in vitro assays can be observed at Figure 1. The inhibition of $T$. vaginalis trophozoites growth was dose-time-dependent, as are shown in the graphic (Figure 2). 
Figure 1 - Antiparasitic activity of free (EO) and nanostructured (NE) essential oils of Cymbopogon flexuosus, Ocimum basilicum and Eucalyptus globulus against Trichomonas vaginalis after 24 hours of exposure. The *** indicate statiscal differences when comparing the groups to the MTZ control by one-way ANOVA followed by Tukey post hoc tests ( $\mathrm{p}<0.05$ ).
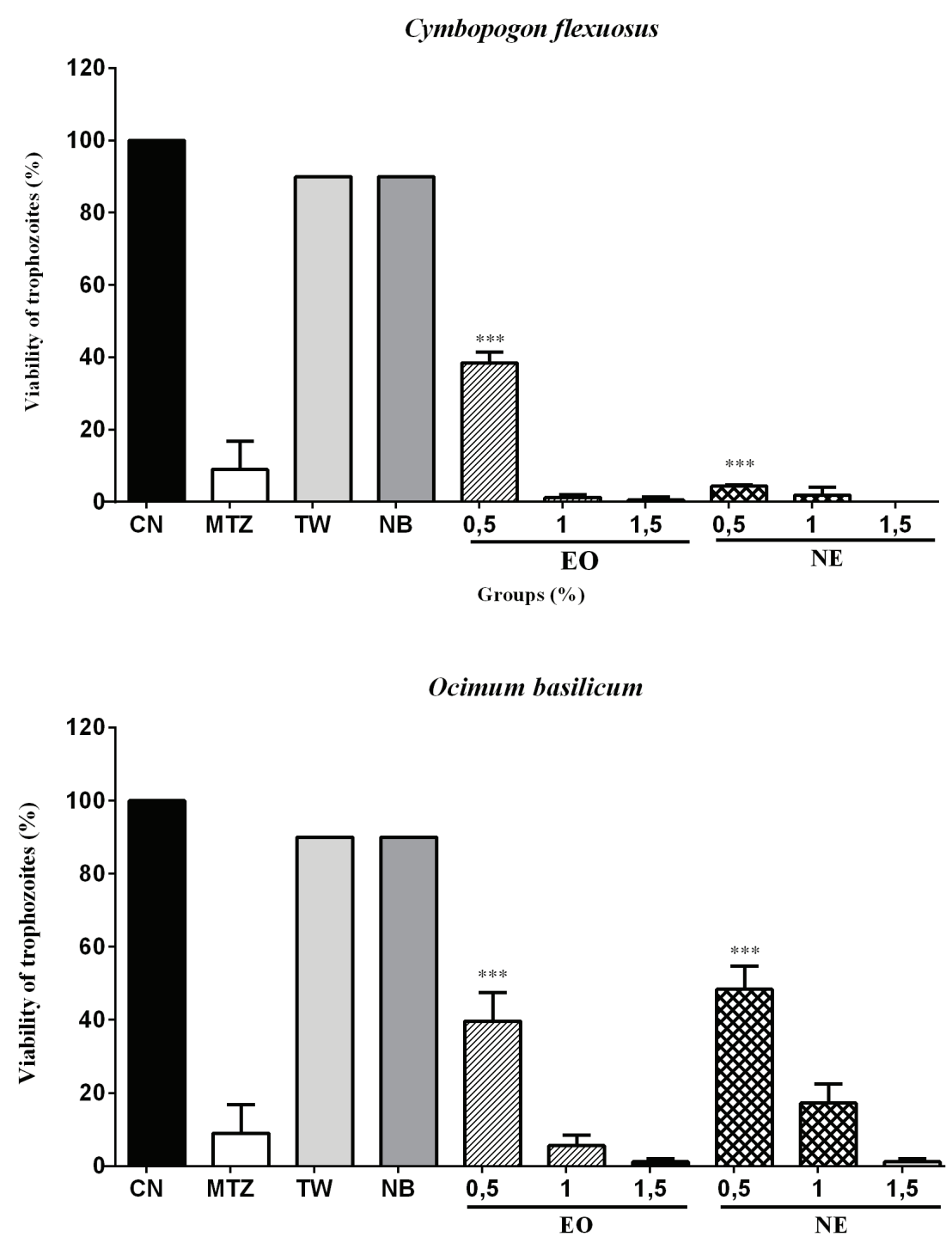

Groups (\%)

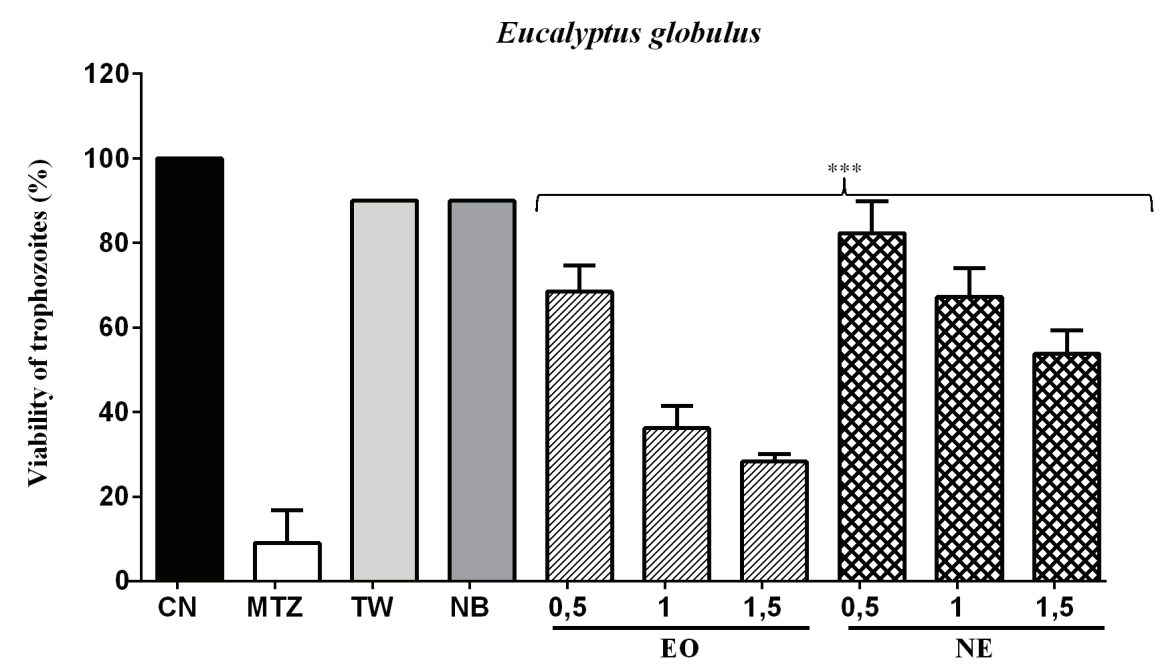

Groups (\%) 
Figure 2 - Time of death of Trichomonas vaginalis isolate (MIC) after exposure to free oils (EO) and nanoemulsion (NE), respectively, of Cymbopogon flexuosus and Ocimum basilicum at 1h, 6h, 12h, 24h, 48, 72h and 96h.
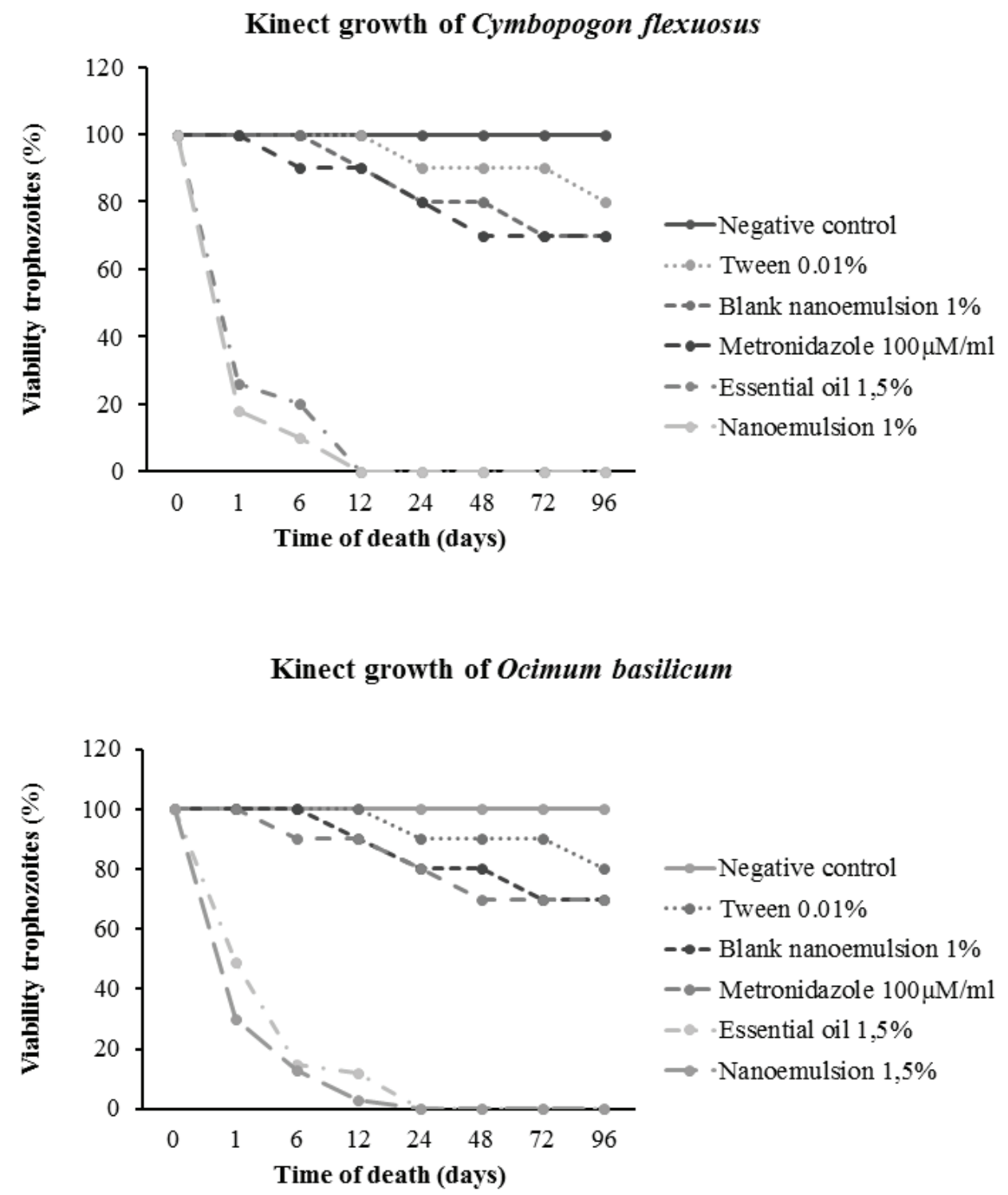

The TBARS assay showed that trophozoites at negative control (NC) increased lipoperoxide levels. Nevertheless, when free EO or nanoemulsions containing these oils were added, as well as Tween 80, peroxidation activity was reduced, showing significant difference when compared to the $\mathrm{NC}$, as shown in the graphic (Figure 3). 
Figure 3 - TBARS assay on Trichomonas vaginalis trophozoites after treatment - free and nanostructured essential oils of Cymbopogon flexuosus, Ocimum basilicum and Eucalyptus globulus
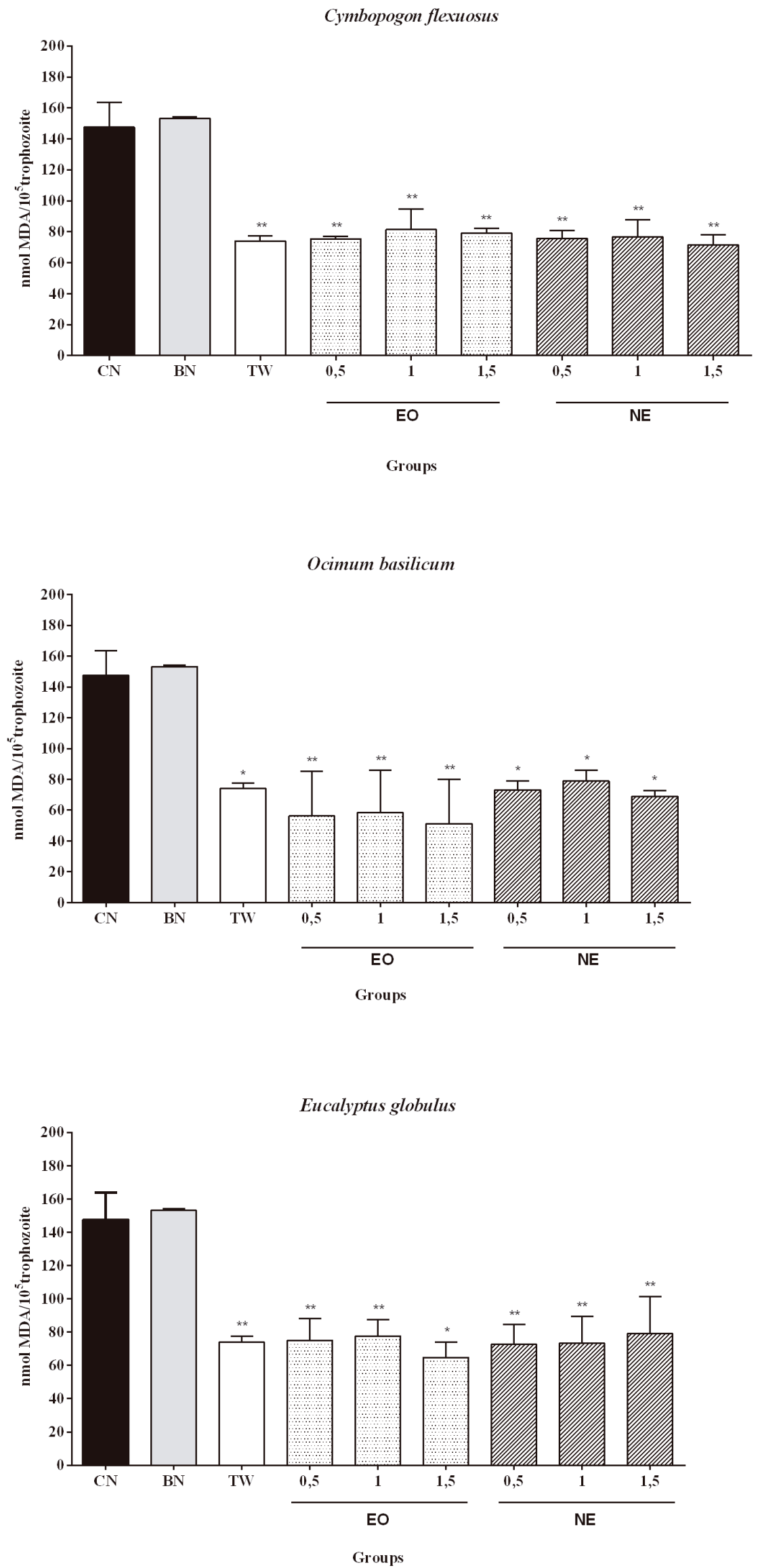


\section{DISCUSSION}

Several reports over the years have shown T. vaginalis resistance when exposed to MTZ, even at low levels (DUNNE et al., 2003; CUDMORE et al., 2004; KIRKCALDY et al., 2011). Studies which aimed to evaluate biological activity, like our research, emphasize the increase of the search for new metabolites with therapeutic value considering the large biodiversity within the Brazilian territory and the potential of natural products in the treatment of diseases (BASSO et al., 2005). Our study found promising results using lemongrass and basil EO, in addition to the new data with nanoemulsion.

In this work, the compounds identified by gas chromatography for C. flexuosus corresponded to the literature. The lemongrass was composed mainly of an isomeric misture of two compounds, alfacitral (geranial) and beta-citral (neral) (KAKARLA; DEEPAK, 2009), and this is the first report of anti-T. vaginalis activity for $C$. flexuosus. In addition to a complex natural mixture, where the synergism between these chemical components could be linked to their promising pharmacological potential (BAKKALI et al., 2008; GALINDO et al., 2010). Thus, they act through different mechanisms of action in several targets within the cells, as in the cell proteins present in the cytoplasmatic membrane (BURT et al., 2004).

Our study found higher trophozoites inactivation of T. vaginalis when treated with lemongrass in both presentations, as detected by Adukwu et al., (2016) against four strains of Acinetobacter baumannii, including two multi-drug-resistant, which showed suscetibility when exposed to $C$. flexuosus, being an alternative for resistant infections. The higher bioactivity of nanostructured clove EOs when compared to free oil and amikacin, was also evidenced in the present study with lemongrass incorporated into nanostructures, presenting similar activity to free oil and MTZ, in lower concentration (ANWER et al., 2004). This highlights the potencial of natural products associated to nanoemulsion droplets, enhancing the biological properties of the components to the target.

Nanotechnology has been used as an alternative to improve the activity of EOs. In our study, this formulation probably contributed for a higher celular absorption and bioefficacy, avoiding the decomposition of these oils due to enviromental factors, thus maintaining stability and decreasing volatility, which can justify the higher activity presented by lower concentrations of lemongrass nanoemulsion when exposed to trophozoites (BILIA et al., 2014). This nanoemulsion was able to reduce the MIC of lemongrass, when compared to free oil, as observed with a nanostructured drug in another study (BALDISSERA et al., 2013; FUENTEFRIA et al., 2014; BAJERSKI et al., 2016). The protection offered by nanostructures to bioactive content enhance the delivery to target, resulting in more effectivenessthan other convencional forms (LOVELYN et al., 2011).

Studies have suggested that the use of drug system delivery in nano size may increase passive cellular absorption, probably through the association of porins and phenolic compounds. This interaction promotes cell breaking due to leakage of ions and others cell contents, increasing the 
bioactivity and consequently the therapeutic efficacy of oils when nanostructured (DONSİ et al., 2012; SALVIA-TRUJILLO et al., 2015), which justifies the better activity of lemongrass nanoemulsion observed in our study against $T$. vaginalis.

Nanostructured systems are prepared from differents materials with dimension ranging from 0.1 to $500 \mathrm{~nm}$. This size and biocompatibility could lead to better penetration into the membrane of the trophozoites and facilitate EO activity, which could explain the significant inhibitory activity observed in our tests. The surface charge of nanoemulsions droplets, also known as zeta potential, is the electrical characteristics of the delivery system drug (MCCLEMENTS et al., 2011). Controlling the charge is a way to control the interactions with the infectuous agent, since the microorganisms have the opposite charges to the nanoemulsions, and when in contact with the oil incorporated into these droplets, there will be electrostatic attraction (ZIANI et al., 2011; CHANG et al., 2015). The electrostatic attraction could be discarded in this study, beacause the nanoemulsion has negative charge and the trophozoites membrane is made up mainly by sialic acid, which contributes to the negative charge of the protozoan (SILVA-FILHO et al., 1986).

The performance of basil against $T$. vaginalis is in accordance with the literature. The same growth inhibitory ability of the EO observed in our research was reported earlier. That study suggests that the antiprotozoal activity observed is probably related to the capacity of basil to inhibit the proteolytic activity of cysteine proteinase, an enzyme present in the life cycle of several protozoan, and the same may occur with T. vaginalis (ELDIN et al., 2015). In our study, the growth inhibition was dose and time dependent and no statistically significant difference was detected when compared to MTZ.

However, there are no reported studies using nanoemulsions containing O. basilicum with anti Trichomonas activity for comparison. This is the first time that the activity of this nanostructured oil was reported against this protozoan. This activity can also be justified by the characteristics characteristics of the EO, which has low density and hydrophobicity that facilitate the delivery of active compounds into specific target cells in parasites (MONZOTE et al., 2012). The literature states that basil oil is composed of terpenes (linalool and geraniol) and phenylpropanoids (methyl chavicol, eugenol, methy leugenol and methyl cinnamate). This varying concentration or presence of major compounds between the species can be justified by environmental factors and the geography of the place where the plant was obtained (ÖZCAN et al., 2005; PANDEY et al., 2014).

Anti-trichomonas activity revealed that no growth was observed after $24 \mathrm{~h}$ of incubation of lemongrass and basil. The mechanism of action of EOs against microorganisms has not been understood yet. Studies have deduced that the bioactive compounds penetrate the phospholipid bilayer after attaching to the membrane, acting directly in the synthesis of the component cell promoting a structural destabilization and consequent death of the parasite (CHOUHAN et al. 2017). The same ability of these oils to inhibit the growth of trophozoites was also observed by Baccega et al (2020) against T. gallinae, confirming the antiprotozoa activity regarding this species. 
The promising pharmacological potential of EOs against parasites could be linked to major compounds or to the synergism within this complex natural mixture, acting through diferents mechanism of action in several targets within the cells, such as the proteins present in the cytoplasmatic membrane (BURT et al., 2004; BAKKALI et al., 2008). The literature suggests that this relationship of bioactives compounds contributes to avoid the emergence of new resistant strains, due to the different receptors that the oil can affect during all stages of the lifecycle of a parasite (ANDRÉ et al., 2018).

Basil and lemongrass oils were identified in this study as potent antioxidants with ability to improve lipid and antioxidant status. EOs can be considered good sources of natural compounds with significant antioxidant activity, which can also be attributed to their main constituents. The capacity of phenolic compounds of donating hydrogen or an electron and removing oxygen from free radicals is responsible for this biological property (SINGH;NISHI, 2015). The reduction of lipid peroxidation observed for the treatments with free and nanostructured oils is confirmed by earlier reports. It is well known that lemongrass is a source of bioactive compounds, flavonoids and vitamins which could inhibit the chain reactions of lipid oxidation, thus justifying the antioxidant activity obtained (IBRAHIM; FERIAL, 2013).

\section{CONCLUSIONS}

Lemongrass and basil are promissing alternatives for the treatment of trichomoniasis. Furthermore, lemongrass showed that the incorporation of oils into nanoemulsions is an attractive option in the developing of new biologically active natural drugs, to promote therapeuthic efficacy in the treatment of this sexually transmitted infection.

\section{ACKNOWLEDGEMENTS}

We thank all the involved at FAMED for providing us the swabs to obtain Trichomonas vaginalis strains.

\section{FUNDING}

This work was supported by grants from the Programa de Apoio a Pós-Graduação (PROAP) and Coordenação de Aperfeiçoamento de Pessoal de Nível Superior (CAPES), Brasília, DF, Brazil.

\section{CONFLICT OF INTEREST}

The authors declare that they have no conflict of interest. 


\section{REFERENCES}

ADUKWU, Emmanuel C. et al., Antimicrobial activity, cytotoxicity and chemical analysis of lemongrass essential oil (Cymbopogon flexuosus) and pure citral. Applied microbiology and biotechnology, v. 100, n. 22, p. 9619-9627, 2016.

ANDRÉ, Weibson Paz Pinheiro et al., Óleos essenciais e seus compostos bioativos no controle de nematoides gastrintestinais de pequenos ruminantes. Acta Scientiae Veterinariae, v. 46, p. 1522, 2018.

ANWER, Md Khalid et al., Enhanced antibacterial effects of clove essential oil by nanoemulsion. Journal of oleo science, v. 63, n. 4, p. 347-354, 2014.

BAJERSKI, Lisiane et al., The use of Brazilian vegetable oils in nanoemulsions: an update on preparation and biological applications. Brazilian Journal of Pharmaceutical Sciences, v. 52, n. 3, p. 347-363, 2016.

BAKKALI, Fadil et al., Biological effects of essential oils-a review. Food and chemical toxicology, v. 46, n. 2, p. 446-475, 2008.

BALDISSERA, Matheus D. et al., Trypanocidal activity of the essential oils in their conventional and nanoemulsion forms: in vitro tests. Experimental parasitology, v. 134, n. 3, p. 356-361, 2013.

BASSO, Luiz Augusto et al., The use of biodiversity as source of new chemical entities against defined molecular targets for treatment of malaria, tuberculosis, and T-cell mediated diseases: a review. Memórias do Instituto Oswaldo Cruz, v. 100, n. 6, p. 475-506, 2005.

BILIA, Anna Rita et al., Essential oils loaded in nanosystems: a developing strategy for a successful therapeutic approach. Evidence-Based Complementary and Alternative Medicine, v. 2014, 2014.

BOUCHEMAL, Kawthar; BORIES, Christian; LOISEAU, Philippe M. Strategies for prevention and treatment of Trichomonas vaginalis infections. Clinical microbiology reviews, v. 30, n. 3, p. 811-825, 2017.

BURT, Sara. Essential oils: their antibacterial properties and potential applications in foods-a review. International journal of food microbiology, v. 94, n. 3, p. 223-253, 2004. 
BACCEGA, Bruna, et al., Free essential oils and nanostructured on Trichomonas gallinae trophozoites. Disciplinarum Scientia| Naturais e Tecnológicas. v. 20, n. 3, p. 337-354, 2020.

CHANG, Yuhua; MCLANDSBOROUGH, Lynne; MCCLEMENTS, David Julian. Fabrication, stability and efficacy of dual-component antimicrobial nanoemulsions: essential oil (thyme oil) and cationic surfactant (lauric arginate). Food chemistry, v. 172, p. 298-304, 2015.

CHOUHAN, Sonam; SHARMA, Kanika; GULERIA, Sanjay. Antimicrobial activity of some essential oils-present status and future perspectives. Medicines, v. 4, n. 3, p. 58, 2017.

CUDMORE, Sarah L. et al., Treatment of infections caused by metronidazole-resistant Trichomonas vaginalis. Clinical microbiology reviews, v. 17, n. 4, p. 783-793, 2004.

DA SILVA GÜNDEL, Samanta et al., Basil oil-nanoemulsions: Development, cytotoxicity and evaluation of antioxidant and antimicrobial potential. Journal of Drug Delivery Science and Technology, 2018b.

DA SILVA GÜNDEL, Samanta et al., Nanoemulsions containing Cymbopogon flexuosus essential oil: Development, characterization, stability study and evaluation of antimicrobial and antibiofilm activities. Microbial pathogenesis, 2018a.

DANIELLI, Letícia J. et al., Antidermatophytic activity of volatile oil and nanoemulsion of Stenachaenium megapotamicum (Spreng.) Baker. Industrial crops and products, v. 50, p. 23-28, 2013.

DE GODOI, Samantha Nunes et al., Evaluation of stability and in vitro security of nanoemulsions containing Eucalyptus globulus oil. BioMed Research International, v. 2017, 2017.

DIAMOND, Louis S. The establishment of various trichomonads of animals and man in axenic cultures. The Journal of parasitology, v. 43, n. 4, p. 488-490, 1957.

DONSİ, Francesco et al., Design of nanoemulsion-based delivery systems of natural antimicrobials: effect of the emulsifier. Journal of biotechnology, v. 159, n. 4, p. 342-350, 2012.

DUNNE, Rebecca L., et al., Drug resistance in the sexually transmitted protozoan Trichomonas vaginalis. Cell research, v. 13, n. 4, p. 239-249, 2003. 
ELDIN, Hayam Mohamed Ezz; BADAWY, Abeer Fathy. In vitro anti-Trichomonas vaginalis activity of Pistacia lentiscus mastic and Ocimum basilicum essential oil. Journal of parasitic diseases, v. 39, n. 3, p. 465-473, 2015.

FUENTEFRIA, Alexandre M. et al., Ketoconazole-Loaded Poly (epsilon-Caprolactone) Nanocapsules for Improved Antifungal Activity Against Candida spp. Latin American Journal Of Pharmacy, v. 33, n. 10, p. 1589-1595, 2014.

GALINDO, Luciane Almeida; DE MORAES PULTRINI, Aline; COSTA, Mirtes. Biological effects of Ocimum gratissimum L. are due to synergic action among multiple compounds present in essential oil. Journal of natural medicines, v. 64, n. 4, p. 436-441, 2010.

HUSSAIN, Abdullah I., et al., Chemical composition, and antioxidant and antimicrobial activities of essential oil of spearmint (Mentha spicata L.) from Pakistan. Journal of Essential Oil Research, v. 22, n. 1, p. 78-84, 2010.

IBRAHIM, Hayam M.; SALEM, Ferial M. Abu. Effect of adding lemongrass and lime peel extracts on chicken patties quality. Journal of Applied Sciences Research, v. 9, n. 8, p. 5035-5047, 2013.

KAKARLA, Shalini; GANJEWALA, Deepak. Antimicrobial activity of essential oils of four lemongrass (Cymbopogon flexuosus Steud) varieties. Med Aromat Plant Sci Biotechnol, v. 3, p. 107-109, 2009.

KIRKCALDY, Robert D. et al., Trichomonas vaginalis antimicrobial drug resistance in 6 US cities, STD Surveillance Network, 2009-2010. Emerging infectious diseases, v. 18, n. 6, p. 939, 2012.

KISSINGER, Patricia. Trichomonas vaginalis: a review of epidemiologic, clinical and treatment issues. BMC infectious diseases, v. 15, n. 1, p. 307, 2015.

MCCLEMENTS, David Julian; RAO, Jiajia. Food-grade nanoemulsions: formulation, fabrication, properties, performance, biological fate, and potential toxicity. Critical reviews in food science and nutrition, v. 51, n. 4, p. 285-330, 2011.

MONZOTE, Lianet; ALARCÓN, Oswald; SETZER, William N. Antiprotozoal activity of essential oils. Agriculturae conspectus scientificus, v. 77, n. 4, p. 167-175, 2012. 
MUZNY, Christina A. Why Does Trichomonas vaginalis Continue to be a "Neglected" Sexually Transmitted Infection?. Clinical Infectious Diseases, 2018.

Ohkawa Hiroshi et al., Assay for lipid peroxides in animal tissues by thiobarbituric acid reaction. Analytical biochemistry, v.95, n. 2, p. 351-358, 1979.

ÖZCAN, Musa; CHALCHAT, JEAN-CLAUSE. Essential Oil Composition of Ocimum basilicum L. Czech J. Food Sci. Vol, v. 20, n. 6, p. 223-228, 2002.

PANDEY, Abhay Kumar; SINGH, Pooja; TRIPATHI, Nijendra Nath. Chemistry and bioactivities of essential oils of some Ocimum species: an overview. Asian Pacific Journal of Tropical Biomedicine, v. 4, n. 9, p. 682-694, 2014.

SALVIA-TRUJILLO, Laura et al., Physicochemical characterization and antimicrobial activity of food-grade emulsions and nanoemulsions incorporating essential oils. Food Hydrocolloids, v. 43, p. $547-556,2015$.

SENA-LOPES, Ângela et al., Chemical composition, immunostimulatory, cytotoxic and antiparasitic activities of the essential oil from Brazilian red propolis. PloS one, v. 13, n. 2, p. e0191797, 2018.

SILVA FILHO, Fernando Costa et al., Further studies on the surface charge of various strains of Trichomonas vaginalis and Tritrichomonas foetus. Cell biophysics. v.8 n.3,p. 161-176,1986.

SINGH, Ishwar. Antimicrobials in Higher Plants: classification, mode of action and bioactivities.

Chem. Biol. Lett, v. 4, n. 1, p. 48-62, 2017.

ZIANI, Khalid et al., Influence of surfactant charge on antimicrobial efficacy of surfactant-stabilized thyme oil nanoemulsions. Journal of agricultural and food chemistry, v. 59, n. 11, p. 6247-6255, 2011. 
